Canadian Journal of Applied Linguistics

Revue canadienne de linguistique appliquée

\title{
Task-Based Language Teaching With a Semantic-Centred Pedagogic Grammar
}

\author{
James W. Gray and Ryan W. Smithers
}

Volume 22, Number 2, 2019

URI: https://id.erudit.org/iderudit/1063775ar

DOI: https://doi.org/10.7202/1063775ar

\section{See table of contents}

Publisher(s)

University of New Brunswick

ISSN

1920-1818 (digital)

Explore this journal

Cite this document

Gray, J. \& Smithers, R. (2019). Task-Based Language Teaching With a Semantic-Centred Pedagogic Grammar. Canadian Journal of Applied Linguistics / Revue canadienne de linguistique appliquée, 22(2), 88-108.

https://doi.org/10.7202/1063775ar

\section{Article abstract}

Task-based language teaching (TBLT) is well known for providing authentic opportunities for second and foreign language (L2) skill development. However, for many learners the use of traditional grammar within TBLT lacks the functional support necessary to create accurate and fluent L2 output. The current study replaced traditional grammar explanations with a semantic meaning-order approach to pedagogical grammar (MAP or MAP grammar) as a means to bridge the language in tasks to their function and thereby strengthen form-to-meaning understanding. The study combined TBLT and MAP grammar to look for changes in the complexity, accuracy, and fluency of 127 L2 learners' writings. The results showed TBLT and MAP separately increased syntactic complexity, whereas the combination of the two provided gains in accuracy and fluency. This was achieved by systematically directing learners' attention to a sequence of functional choices thereby simplifying necessary metalinguistic explanations.
Copyright (c) James W. Gray, Ryan W. Smithers, 2019

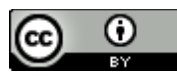

This document is protected by copyright law. Use of the services of Érudit (including reproduction) is subject to its terms and conditions, which can be viewed online.

https://apropos.erudit.org/en/users/policy-on-use/ 


\title{
Task-Based Language Teaching With a Semantic-Centred Pedagogic Grammar
}

\author{
James W. Gray \\ Fukui University \\ Ryan W. Smithers \\ Otani University
}

\begin{abstract}
Task-based language teaching (TBLT) is well known for providing authentic opportunities for second and foreign language (L2) skill development. However, for many learners the use of traditional grammar within TBLT lacks the functional support necessary to create accurate and fluent L2 output. The current study replaced traditional grammar explanations with a semantic meaning-order approach to pedagogical grammar (MAP or MAP grammar) as a means to bridge the language in tasks to their function and thereby strengthen form-tomeaning understanding. The study combined TBLT and MAP grammar to look for changes in the complexity, accuracy, and fluency of 127 L2 learners' writings. The results showed TBLT and MAP separately increased syntactic complexity, whereas the combination of the two provided gains in accuracy and fluency. This was achieved by systematically directing learners' attention to a sequence of functional choices thereby simplifying necessary metalinguistic explanations.
\end{abstract}

\section{Résumé}

L'enseignement des langues basé sur les tâches est bien connu pour fournir des occasions authentiques d'apprentissage de la langue seconde ou étrangère (L2). Néanmoins, pour plusieurs apprenants, l'usage de la grammaire traditionnelle dans l'approche basée sur les tâches ne fournit pas le soutien fonctionnel nécessaire à une production précise linguistiquement et fluide. La présente étude a remplacé les explications de grammaire traditionnelles par une approche de la sémantique instructionnelle servant de pont entre le langage dans les tâches et leur fonction, ce qui renforce la compréhension des liens entre la forme et le sens. Cette étude a combiné l'approche d'apprentissage des langues basé sur les tâches et l'approche de la sémantique instructionnelle pour examiner la complexité, la précision linguistique et la fluidité dans les productions écrites de 127 apprenants de L2. Les résultats ont démontré que l'apprentissage des langues basé sur les tâches et que la sémantique instructionnelle augmentaient séparément la complexité syntaxique, tandis que la combinaison des deux approches a contribué à l'amélioration de la précision linguistique et de la fluidité. Ceci a été atteint en dirigeant l'attention des apprenants vers une séquence de choix fonctionnels simplifiant ainsi les explications métalinguistiques nécessaires. 


\section{Task-Based Language Teaching With a Semantic-Centred Pedagogic Grammar}

\section{Introduction}

Task-based language learning is generally a simultaneous process of learning two separate knowledge domains. The first involves learning the language required to complete the task, while the second involves learning the language required to speak about language - the metalanguage. In essence, the language required to complete tasks in taskbased language teaching (TBLT) is task-specific, with each task bound to contexts. Tasks, consequently, not only offer new second and foreign language (L2) learning opportunities and choices, but they can also help learners more quickly and accurately understand how lexicogrammatical choices in a new task operate (Ellis, 2012). Furthermore, learning how to complete tasks necessitates learning the language particular to each and every context and, possibly, metalinguistic expressions.

Within this second knowledge domain, metalinguistic explanations have been shown to be an effective aid for learners in the completion of tasks. Explicit talk about the language is often referred to as focus on form (FonF). Second language acquisition (SLA) research has shown how FonF is effective at promoting more accurate use of the L2 (Spada $\&$ Tomita, 2010), but sometimes less so at demonstrating communicative control in fluent use (Shintani, 2013). Metalinguistic explanations can be either term or process based (Berry, 2010). However, since traditional grammar explanations tend to be term based, they may not facilitate an understanding of how grammatical processes function. Conversely, a semantic meaning-order approach to pedagogical grammar (MAP or MAP grammar) systematizes explanations of metalinguistic processes on a semantic basis within each task, thereby making the process of meaning making within the task easier to understand.

The aim of this paper is to show how MAP grammar is superior to other, traditional approaches to grammar teaching in TBLT. Accordingly, the first section of this article begins with a review of the literature on TBLT. This is followed with an introduction to MAP grammar and a discussion on how MAP grammar can be operationalized within TBLT. Next, a case study of Japanese L2 university students is presented. Lastly, this paper closes with an analysis of the findings from the study and presents a list of takeaways for practitioners who might want to open themselves up to a new way of approaching language pedagogy by combining MAP grammar and TBLT.

\section{Literature Review}

Definitions of task in TBLT vary, but four main principles are consistently shared (Ellis, 2003; Long, 2000; Robinson, 2001, 2011; Skehan, 1998b). A task must primarily (a) focus on pragmatic meaning, (b) involve some kind of gap, as well as (c) be authentic in nature, and finally (d) have a clearly defined, non-linguistic outcome. Tasks in TBLT classes tend to be practical in nature rather than theoretical and for Ellis (2003) this meant based on meaning and not explicitly on grammatical form. Within TBLT certain aspects of the task are intentionally withheld, thereby creating gaps, that is, L2 challenges. These gaps might vary in nature, such as gaps in information, reasoning, or opinion (Prabhu, 1987), but overcoming them is a necessary component to accomplishing the task. Tasks in TBLT should also provide a frame of reference for how the language is applied in the real world 
and opportunities for meaningful practice. Upon completion of the task, learners can expect to receive a payoff directly related to overcoming the task.

Combing the strengths of two approaches to teaching the L2 is a central goal of TBLT. The first is a synthetic approach, in which grammar is synthesized into communicative use, and the second is an analytic approach, where communicative use is analyzed to understand the grammatical forms. These attempts have resulted in a hybrid analytical approach in which traditional grammatical form instruction is included in taskbased L2 skill instruction, originally termed an analytic approach with a FonF (Long, 1991, 2003, 2009; Long \& Robinson, 1998). Long and Robinson (1998) developed FonF for TBLT to meet the needs of learners as they engage in specific tasks. Its aim was to attract attention to the grammatical forms required by learners to solve task-related problems. This allowed task content to be central to class discussions, yet still permitted consideration of grammatical form.

The coupling of FonF to TBLT has focused much TBLT research on the effects of increased task complexity on learners' output (Robinson, 2001; Skehan, 1998a), where increased task difficulty alone leads to various changes in complexity, accuracy, and fluency (CAF) whereas other TBLT studies have also included how different types of FonF error correction techniques influence CAF output. A good example of these is Révész, Sachs, and Hama's (2014) work on how recasts, or repeating a repaired version of the learners' output, are influenced by the reasoning demands in a complex or simple task. A recast is the most common error correction technique in TBLT (Lyster \& Ranta, 1997) but it is less effective at improving writing since learners do not consistently modify their output after a recast (Yang \& Lyster, 2010). Like many FonF error correction techniques, recasts rely on an implicit request to learners, which some find ambiguous and often mistake for a confirmation of classroom content and not error correction (Sato, 2011). Although the error correction technique may vary throughout these TBLT studies of FonF, the common denominator is the use of traditional grammar terms and metalanguage. Very little research has explored the use of alternative approaches to explicit grammar instruction in TBLT. The present study helps fill this gap by using MAP or MAP grammar (Tajino, 2018) within TBLT.

Customarily for TBLT, traditional grammar descriptions are fixed, based on terminology, and do not change with each successive task. However, MAP grammar views metalinguistic descriptions as flexible and contextually driven. For TBLT, how and what is learned primarily depends upon what each successive task sets before the learners. To successfully complete a given task, L2 learners may need to learn how a specific grammar form has changed function and usage within a new task context, which can be difficult using a fixed grammatical term. That is to say, for TBLT learning the L2 is task-specific but not necessarily grammar-specific. The requirements of a specific task define not just the learning opportunities but also the grammatical choices available to learners. Therefore, having grammatical descriptions that adapt to the context of each task makes it easier for learners to understand, remember, and apply them correctly.

Grammatical descriptions of language in MAP grammar encourage learners to think in terms of units of functional meaning and prompt learners to consider how these units operate within each specific task. This does not mean traditional grammar is totally abandoned; MAP grammar in the classroom often does employ some traditional metalanguage. However, thinking of grammatical proficiency as task-specific means the 
purpose of grammar is to flexibly adapt descriptions of form within a task to their present function and in doing so adapt L2 form instruction to the learners' existing context.

The synergy generated by partnering MAP grammar and TBLT provides learners

with the means to systematically create L2 output in an environment that mirrors real world use, all the while benefiting from explicit contextually-aligned lexicogrammatic instruction. Within this partnership, MAP grammar furnishes a systematic means to increase fluent and accurate L2 output. The pragmatic environment delivered by TBLT is conducive to encouraging practical use that is pedagogically supported by MAP grammar's explicit contextual feedback. This synergy results in a linguistically-based understanding of the task environment and the ability to correctly produce the necessary L2 output intrinsic to successfully accomplishing L2 tasks within that task environment.

\section{An Introduction to MAP Grammar}

Within the MAP grammar approach, English is viewed as a fixed word order language. According to Halliday (1985a), the term fixed word order does not solely refer to the order of the words but also more generally the order of certain elements. Halliday (1985b) posited that there are two elements to every clause: the theme and the rheme.

The theme, as the initial element of the clause, always appears first. For Halliday (1994), the clause is the highest-ranking unit of grammar, followed by word groups and then words. Halliday (1994) interpreted a sentence as a clause complex - a head clause together with other clauses that modify it - thereby accounting for the functional organization of sentences (Halliday, 1994). A clause is seen to represent a single "communicative event . . . organized as a message by having a special status assigned to one part of it" (Halliday, 1994, p. 37). Halliday (1985a) hypothesized that the basic organizing principle of language is functional and assigned the theme a special status. The theme provides specific content to develop the clausal message. The theme is "the element which serves as the point of departure of the message. It introduces the main information to be conceived later by the rheme" (Halliday, 1985b, p. 38). Consciously or unconsciously, English speakers tend to put the most functionally important information in the theme, and it is the order of elements - first theme and then rheme - that create the fixed sequence of the language.

The special status given to the theme's initial position in English is not a universal trait. The theme of a clause in Japanese, for example, is followed by the particle wa or ga (Halliday, 1994). However, the theme in Japanese is often completely omitted in practical use. For English, this order is so important that special provisions are in place to warn users that the sequence has changed. For example, passive voice construction moves the agent of the action from the beginning to the middle of the sequence. This rearrangement in order is marked with two warnings (Bever, 2013). Passive voice entails a specific verb construction (be + past participle) and an additional preposition (by) to mark the agent of an action. These serve as warnings that the preferred sequence in not being followed.

This fixed sequence of the language is referred to as a syntagmatic relationship. A syntagmatic relationship is composed of one or more syntagm, which are units of meaning consisting of a set of linguistic forms in a sequential relationship with one another. In the case of MAP grammar, a syntagm refers to individual words or word groups within a clause engaged in a syntagmatic relationship on a semantic basis. The meaning constructed is the only criterion for determining if sequential syntagm are involved in the same syntagmatic 
relationship and thus grouped together and given a semantic label, hereafter referred to as a tag. Related syntagm are bundled by MAP grammar into one of six tags: Alpha $(\alpha)$, Who, Does, What, Where, and When.

Figure 1 is a representation of the MAP sequencing of the English language's syntagmatic relationship. The round black circles represent syntagm, which have been encircled into a syntagmatic relationship via the tag. The white arrows indicate the flow of information through the preferred sequence.

The above MAP tags are self-descriptive by nature, with the exception of the first tag - the Alpha tag. As MAP analysis is difficult to discuss without content, the following example (Ex. 1) briefly outlines the tagging process.

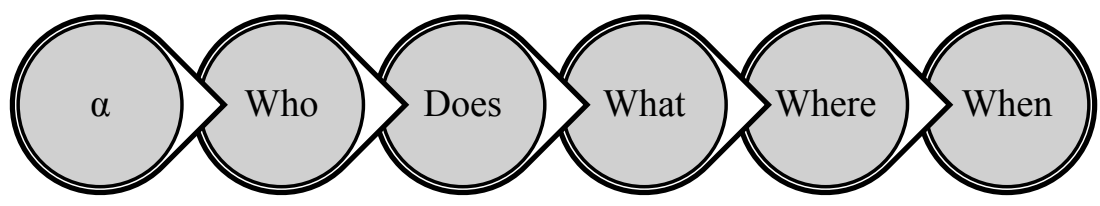

Figure 1. Meaning-order approach to pedagogical grammar (MAP grammar), the syntagmatic sequencing of the English language (Smithers \& Gray, 2018)

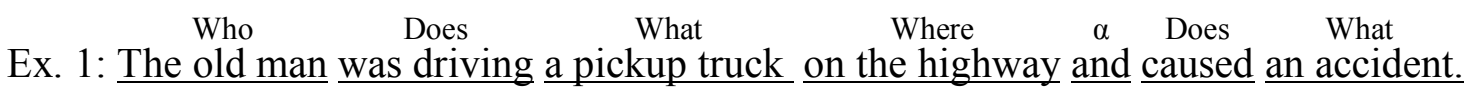

In the first position, the Alpha tag operates in two capacities. It first operates as a connector of clauses to show how two sequential clauses are semantically related. An Alpha in this role usually consists of a single syntagma, for example and, but, therefore, et cetera, as in Ex 1. In this role, the Alpha tag represents a higher level of language since it connects clauses as opposed to individual syntagm. Alpha use increases as learners gain in L2 written ability and grammatically connect other tags but then gradually declines as they begin to create more nominal groups in their writing. The second role of the Alpha tag is for mapping interrogatives. The MAP grammar approach simplifies question construction by making apparent how a question is created. This approach places the Alpha tag in front of the clause. The targeted answer is indicated by the tag name used in the body of the question (Ex. 2).

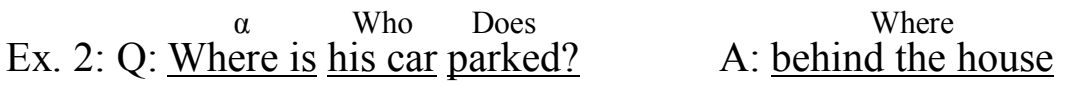

In the second position, the Who tag is the source of actions, feelings, or existence in the clause. Together with the Alpha tag, these represent a special and higher status of information and can be equated with Halliday's (1985a, 1985b) theme. From within the theme, the Who and Alpha tags characterize and influence all the details positioned later in the sequence. For example, in Ex. 1 the Who tag "The old man" influences how we perceive the later tags and may help explain why many would accredit the driver's age as the primary cause of the accident and not the pickup truck or the highway.

The remaining tags-Does, What, Where, and When - constitute the rheme. The Does tag indicates to the listener what activities are being engaged in by the Who. It also relates event timing (through tense). In the fourth position, the What tag is an umbrella term 
that subsumes anything the Who has acted upon. It could be an actual physical thing, how the action was carried out, or a person involved in the action. In the fifth and sixth positions, the Where and When tags inform on the location and the timing of events the Who is involved with. These rheme tags are of less importance since they are primarily modifying our understanding of the Who and Alpha tags.

As stated above, the theme and rheme create the fixed word order of English. This order is represented in MAP grammar through a reoccurring, pedagogically-oriented sequence of tags, namely Alpha, Who, Does, What, Where, and When ad infinitum. As an example, see Table 1. For L2 learners, what is important is simply recognizing this reoccurring clause sequence and adopting it into their L2 analysis and output.

Table 1

An Example of Meaning-Order Approach to Pedagogical Grammar (MAP Grammar) Tagging and Analysis

\begin{tabular}{|c|c|c|}
\hline \# & Theme & Rheme \\
\hline 1. & $\begin{array}{c}\text { Who } \\
\text { Parts of the west coast of Japan }\end{array}$ & 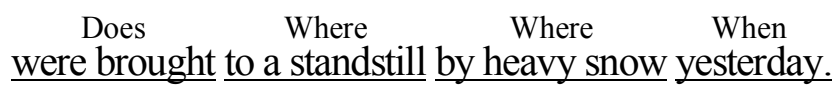 \\
\hline 2. & $\begin{array}{c}\text { Who } \\
\text { Fukui prefecture }\end{array}$ & $\begin{array}{l}\text { Does What } \\
\text { was worst hit. }\end{array}$ \\
\hline 3. & $\begin{array}{c}\text { Who } \\
\text { All the schools }\end{array}$ & $\begin{array}{c}\text { Does } \\
\text { Where } \\
\text { were closed in the prefecture, }\end{array}$ \\
\hline 4. & $\begin{array}{c}\alpha \\
\text { Who } \\
\text { where } 1000 \text { vehicles, }\end{array}$ & $\begin{array}{l}\text { Does } \\
\text { Where } \\
\text { were stranded on national Route } 8 \\
\end{array}$ \\
\hline 5. & $\begin{array}{l}\text { Who } \\
\text { and more than } 80 \mathrm{~cm} \text { of snow }\end{array}$ & $\begin{array}{l}\text { Does } \\
\text { Where } \\
\text { was recorded in the Hokuriku region. }\end{array}$ \\
\hline 6. & $\begin{array}{l}\text { Who } \\
\text { The Meteorological Agency }\end{array}$ & $\begin{array}{c}\text { Does } \begin{array}{c}\text { What } \\
\text { warned the public }\end{array} \\
\end{array}$ \\
\hline 7. & $\begin{array}{l}\alpha \\
\text { that heavy snowfall }\end{array}$ & $\begin{array}{l}\text { Does } \\
\text { What } \\
\text { could continue to fall through Wednesday. }\end{array}$ \\
\hline
\end{tabular}

Note. Adapted from: Japan times, February 7, 2018.

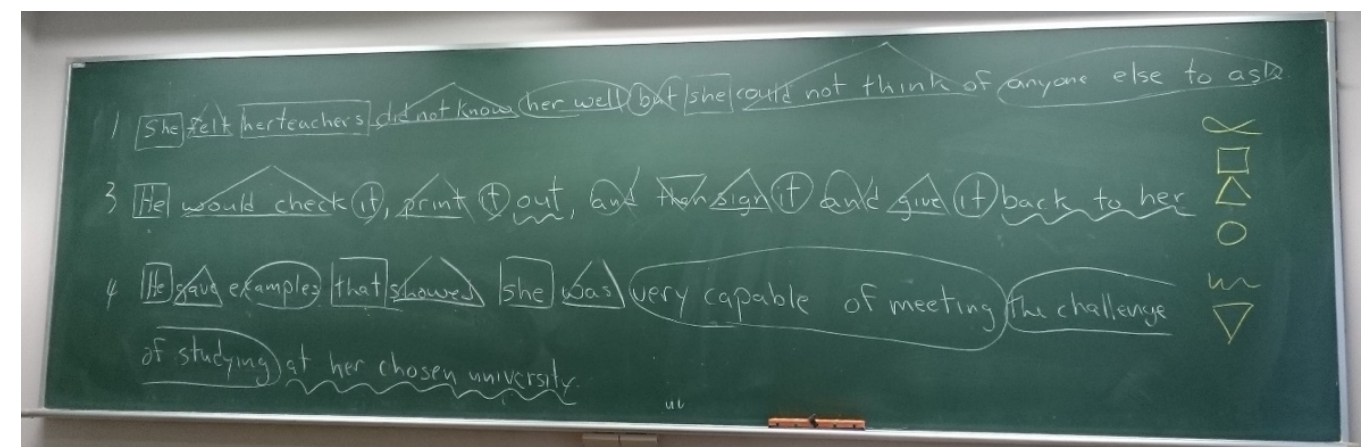

Figure 2. Meaning-order approach to pedagogical grammar (MAP grammar) tagging in the classroom. 


\section{Incorporating MAP Grammar Into TBLT}

First, MAP grammar is fairly intuitive, with the class time required to cover basic tenets at about 30 to 50 minutes. In class, MAP grammar adapts tag use to the TBLT classroom and on the blackboard or paper replaces tags with symbols - alpha symbol, square, circle, triangle, wavy line, and inverted triangle - for the MAP sequence respectively (see Figure 2). The use of symbols allows learners to tag large amounts of text quickly. The text in Table 1 would take most learners about 10 to 15 minutes to tag and will be used to show how MAP grammar maintains a focus on classroom content related to a task, increases peer discussions, and improves form-to-meaning connections.

In Table 1, line 1 a learner has tagged "by heavy snow" as a location with a Where tag. Most learners would unquestionably assign just "heavy snow" a What tag, but the addition of a preposition often transforms What tags into locations or times. Following this thinking, "by" has for this learner transformed the semantic meaning into a location. The learner possibly views both the snow and its specific location on the west coast of Japan as two components of the agent that has caused the standstill. The learner's partner may question this tagging decision and argue the "by" refers to just the snow, a What tag, since the standstill is a result of its appearance. The partner could further argue the "by" is actually part of the Does tag's use of the past passive and point out this agent is implicitly present throughout the text in lines 3, 4, and 5 but has been explicitly excluded because the reporter wanted to focus readers' attention on the schools and vehicles at a standstill and not on the snow.

Of the above two semantic interpretations, which is the most grammatically precise is of limited importance to TBLT. For TBLT, learners' attention remained almost exclusively focused on pragmatic meaning while they achieved a FonF connection. The learners employed content - how the location of or the result of snow has interrupted life in the area - to discuss their semantic interpretation of grammatical form. Specifically, they focused on whether "by" was being used as a preposition indicating location or as part of the passive past tense. For MAP grammar, grammatical descriptions are flexible and contextually-driven. Different interpretations of context leading to comparisons of tag assignments are at the heart of gaining an understanding of how form is operating within context. Research on MAP grammar has shown such comparisons increase peer discussions of content and grammar and improve learners' motivation to study the L2 (Smithers, 2018; Smithers \& Gray, 2018) as well as increase the L2 learners' accurate understanding of complex grammatical structures (Kurihara, Kawanishi, \& Sakamoto, 2018).

Part of the reason for this increase in learners' accuracy is the systematic and explicit nature of error correction within MAP grammar. In order to provide explicit functional direction to metalinguistic descriptions, MAP tags are systematically sequenced. Error correction in MAP grammar always begins with the tag name (e.g., Where), which intuitively depicts a specific semantic function and through the ordered sequence indicates its location within the clause. Once identified and located, the tag criterion is used to highlight how grammatical form, semantic function, and task content are not aligned.

Who
Ex. 3.1: One of life's pleasures is having breakfast at noon. 
For example, in Ex. 3.1 a learner has tagged the gerund as the present progressive tense instead of as the complement of the verb to be. As a result, the Does and the When tags do not agree in terms of when breakfast is enjoyed. The learner is thus made aware their grammatical output is not correct in terms of its presentation of action or time. To correct the error, the When tag could to be changed to the present moment, but such a change would not align with the content of the task with which the learner is engaged. However, assigning the gerund a What tag does succeed in aligning content, semantic function, and grammatical form (see Ex. 3.2).

\section{Ex. 3.2: One of life's pleasures is having breakfast at noon.}

These error correction techniques make MAP tags very effective at almost completely eliminating global errors, that is, errors that distort meaning to the point of hindering comprehension (Burt, 1975). This leaves L2 learners to correct only local errors and, encouragingly for the learners, gives them confidence they will be understood despite grammatical missteps (Gray, 2018).

Ideally suited for beginner to intermediate L2 learners, MAP grammar also works very well for learners who struggle with the fluency or accuracy of their L2 output. In 2011, MAP grammar instruction was introduced for the first 15 minutes of each Grade 7 English class via task-based writing in Saga Prefecture, Japan. Prior to its introduction, students often translated entire Japanese sentences in order to write them in English and were unable to express their own ideas clearly. At the time, Saga was ranked well below the national average in terms of students' writing ability. After the introduction of MAP instruction, by 2014 Saga Prefecture was ranked above the national average in all four English skill areas - listening, speaking, reading, and writing - with improvement in writing considered "remarkable" (Jojima, Oyabu, \& Jinnouchi, 2018).

Additionally, MAP grammar can also greatly help learners who struggle with fluency, particularly in locations where English is not commonly spoken. Coupled with TBLT, MAP grammar aids these learners by increasing L2 fluency. By predetermining the order of a clause, MAP grammar helps improve automation of learners' output, which is a necessary component of meaningful L2 communication (Levelt, 1978). Such predetermination decreases the number of decisions required to create output. Faced with fewer decisions, learners have more time to devote to communicating task content, thereby increasing their L2 fluency levels.

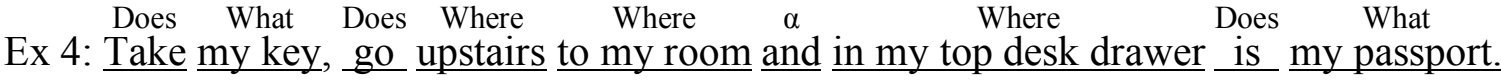

Fortunately, such preestablished ordering of output does not decrease learners' creative expressions of L2 meaning, since learners quickly begin to modify the MAP sequence to the task at hand. This modification is pedagogically encouraged because it reflects the learners' choice to align their output to the needs of the task it is designed to accomplish. In Ex. 4, the task at hand has altered the MAP sequence. Learners' choices with regard to completing the task have placed a larger amount of imperative information in the theme, which is most likely to provide directions to retrieve the speaker's passport. As learners respond more to the demands of the task, they tailor the order of the MAP 
sequence to the task and their output becomes more creative and original while maintaining grammatical accuracy.

\section{The Present Study}

The present study investigated the effect of MAP grammar within a TBLT class on the complexity, accuracy, and fluency on learners' written output as manipulated by causal reasoning demands (Robinson, 2001, 2005, 2007b, 2011). For this reason, a brief summary of research related to causal reasoning is provided below.

Robinson (2005) claimed causal reasoning involves more than simple transmissionof-information tasks because it requires a rationale to support a specific explanation of events people are engaged with, intentionally caused or otherwise. Most studies have operationalized causal reasoning demands through learners' descriptions of pictures since causality can be inferred from the L2 context (Levinson, 1983). However, the narration of sequenced-picture tasks is seen as inappropriate to test causal reasoning demands because learners are simply identifying a pre-existing structure (Robinson, 2007a).

Wolff (2003) varied the root cause of events in his causal reasoning study, for example, with intentional or unintentional outcomes of certain actions. Wolff found that intentionality influenced the linguistic construction. If the outcome was intentional, speakers preferred a lexical construction (A child started the fire.), whereas if the outcome was unintentional they preferred a periphrastic construction (A child made the fire start.). In general, unintentional events or those involving an intermediate object usually use a periphrastic construction, making the output more syntactically complex.

Finally, most studies have used dyadic tasks to study the effect of causal reasoning demands on L2 output. However, Robinson (2005) argued monologic tasks may better facilitate the use of more complex syntax, since learners' linguistic production is reduced by the demands of working with a partner. With the above information in mind the study asked the following research questions.

\section{Research Questions}

1. To what extent does the combination of MAP grammar and task complexity affect measures of syntactic complexity?

2. To what extent does the combination of MAP grammar and task complexity affect measures of grammatical accuracy?

3. To what extent does the combination of MAP grammar and task complexity affect measures of fluency?

\section{Participants}

A total of 127 Japanese learners participated in the study: the experimental group consisted of four classes $(N=90)$ and the control group of two classes $(N=37)$. Participation was entirely voluntary and non-participation had no impact on class assessment. All learners were 22 to 26 years old and majoring in engineering at a Japanese national university. All had a minimum of eight years of previous formal English education and can be described as intermediate, or at the B1 level on the Common European Framework of Reference for Languages (CEFR). Learners were grouped based on their 
engineering specialization, not L2 ability, and four learners who had more than four months' experience of study abroad were excluded from the study.

\section{Treatment}

All learners took part in 15 TBLT classes of 90-minute length over the course of a university term. For the experimental group, the first three classes were used to introduce MAP grammar. The first class was used to explain basic tenets and reasons MAP was adopted for the class, while the next two classes were used to improve learners' MAP tagging skills.

Class content consisted of 50 unrelated stories, which gradually increased in length, starting from 165 and reaching 640 words in length. Throughout the term, all learners worked in pairs and the use of both Japanese and English was encouraged in order to promote a focus on understanding classroom content. Instructors presented all stories orally in the L2 and provided opportunities for pairs to ask for content clarification, which was always provided in the L2. Learners were required to gain an understanding of content orally and were never given a written copy of the stories.

After learners gained an initial understanding of a story, they were required to complete a series of reasoning-gap tasks related to its content. This involved deriving a significant amount of new information from a story that was not explicitly included in the original telling and therefore necessitated a strong comprehension of the initially presented information. Learners extrapolated new information through processes of inference, deduction, and interpretation of the characters' characteristics, relationships, or patterns of behaviour. For example, based on the information provided in a story, learners had to determine a speaker's relationship to other characters, the exact age of a character, a daily commuting time, or the probability a character wore eyeglasses. Overcoming these reasoning-gap tasks provided learners with a fuller social picture of the characters and the issues presented in the stories. The next task for the learners was to incorporate this new information into their version of the story through a retelling, either orally or in writing. Each class consisted of two to four stories with the above steps undertaken for each story.

For the class, there were no specific grammatical items targeted with error correction originating solely from content-related issues followed by a recast. The instructor never initially provided the recast; instead, all learners were asked to recast the sentence for themselves after receiving explicit metalinguistic corrections.

Explicit metalinguistic discussions and corrections related to metalanguage descriptions of the stories were the only difference between the experimental and control group. For the experimental group, all metalanguage discussions and grammatical corrections were related through MAP grammar via a story's content. The content of the stories was used to demonstrate how learners' MAP tagging decision may have created an unintended or unclear meaning in their output. For example, in Japanese, it is perfectly acceptable to use the copula with the verb. Thus, Japanese L2 learners of English sometimes double the verb (Narahara, 2002), as in Mariko is play tennis in the park. This would be corrected via MAP grammar by pointing out the time frame of the Does is unclear because the sentence has two Does tags and then asking the learner to recast the sentence. Learners were asked to recast for themselves in order to facilitate application of MAP's systematic tenets to self-repairing output. For the control group, metalanguage discussions and grammatical corrections took place using traditional grammatical terms and 
metalanguage, with the corrections also being related to the story's content. The above example would be corrected by pointing out the verb tense is incorrect and requesting a recast. The control group was asked to recast for themselves to make a distinction between error correction and confirmation of classroom content. To restate, the only difference between the experimental and control group was the language and symbols used when the language itself was being discussed or examined.

\section{Data Source}

Data for the study came from a written pretest task undertaken at the start of the term and a posttest task undertaken in the last class of the term. Taking the above research into causative reasoning into account, this task consisted of an individual counter-balanced, open-ended writing task to avoid the influence of working with a partner. Learners wrote for 15 minutes about a single drawing depicting a driver engaged in an activity that violated a traffic law. On the pretest, learners were instructed to simply describe the picture, whereas on the posttest learners were instructed to describe the crime committed and hypothesize about possible effects of the violation. The picture provided learners with the ability to infer causality involving a number of potential outcomes. Learners were also asked to rate the pre- and posttest task difficulty on a five-point Likert scale (Révész, Michel, \& Gilabert, 2016). In line with Robinson (2005), the above conditions increased the cognitive complexity of the task conditions by increasing a task-directing resourcespecifically, causative reasoning - and made learners more likely to incorporate and attend to linguistic output during the more complex task.

The written output from the task was examined for the number of t-units, sentences, clauses, causative constructions, error free t-units, and words. A $t$-unit is the "shortest grammatically allowable sentences or minimally terminable unit" (Hunt, 1965, p. 21). Tunits were chosen because the single speaker nature of the task made their use appropriate compared to c-units (conversation-units) which are more appropriate for dialogue. These data were used to calculate five measures of syntactic complexity, two of accuracy, and one of fluency (see Table 2).

Measures of complexity, accuracy and fluency. Syntactic complexity can be measured in terms of the number of different syntactic constructions used in the writing. Lexical complexity was not included in the study due to the relatively short length of the written responses. For accuracy, there were no targeted grammar or obligatory context measures in the study. Similar to Ishikawa (2007), the present study excluded errors in spelling and punctuation, but included errors in morphology, lexicality, syntax, and discourse. Written fluency was measured by how many words a learner wrote in the allotted task time. Table 2 shows a description and formula for each measure. 
Table 2

Measures, Descriptions, and Formulas for Complexity, Accuracy, and Fluency

\begin{tabular}{|c|c|c|}
\hline Measure & Description & Formula \\
\hline \multirow{5}{*}{$\begin{array}{l}\text { Complexity } \\
\text { (Syntactic) }\end{array}$} & 1. Over-all complexity: average length & A. \# words / \# t-units \\
\hline & & B. \# words / \# sentences \\
\hline & $\begin{array}{l}\text { 2. Subordination: use of subordinate or } \\
\text { dependent clauses }\end{array}$ & \# clauses / \# t-units \\
\hline & $\begin{array}{l}\text { 3. Sub-clausal complexity: nominal or } \\
\text { infinitival clauses }\end{array}$ & \# words / \# clauses \\
\hline & $\begin{array}{l}\text { 4. Causative constructions (cc): Relates two } \\
\text { events. An actor initiates something } \\
\text { causing the second event. }\end{array}$ & \# cc / \# t-units \\
\hline \multirow[t]{2}{*}{ Accuracy } & 1. Error free $t$-units & \# error-free \\
\hline & 2. Ratio of error free to t-units & \# error-free / \# t-units \\
\hline Fluency & 15 minutes of task time & words / minute \\
\hline
\end{tabular}

\section{Results}

Evidence tasks increased cognitive demands. Tables 3 and 4 show descriptive statistics for task difficulty ratings for the pretest and posttest for the experimental and control group, respectively. Specifically, means, standard deviations, medians, standard error, and values for kurtosis and skewness were computed in order to gather information on the central tendency, variability, and distribution of scores. As predicted, learners' difficulty ratings increased from the pretest to the posttest, with all learners clearly viewing the task on the posttest as more difficult than the task on the pretest.

Table 3

Experimental Group ( $\mathrm{N}=90)$ Descriptive Statistics for Task Difficulty Ratings

\begin{tabular}{lllllll}
\hline & $M$ & $S D$ & $\mathrm{mdn}$ & $S E$ & Kurtosis & Skewness \\
\hline Pretest & 2.09 & 0.94 & 2.00 & 0.10 & -1.13 & 0.23 \\
Posttest & 3.10 & 1.02 & 3.00 & 0.11 & -0.80 & 0.06 \\
\hline
\end{tabular}


Table 4

Control Group ( $\mathrm{N}=37)$ Descriptive Statistics for Task Difficulty Ratings

\begin{tabular}{lcccccc}
\hline & $M$ & $S D$ & $\mathrm{mdn}$ & $S E$ & Kurtosis & Skewness \\
\hline Pretest & 2.06 & 0.97 & 2.00 & 0.23 & -0.98 & 0.34 \\
Posttest & 3.18 & 1.13 & 3.00 & 0.27 & -0.62 & -0.09 \\
\hline
\end{tabular}

For both pre- and posttests, two native English teachers calculated the number of tunits, sentences, clauses, causative constructions, error free t-units, and number of words for each learner. They achieved an average Pearson's inter-rater reliability score of $r=.993$. The tests were found to be reliable with a Cronbach's alpha of 0.81 for 12 items.

The remainder of the results will be presented with reference to the research questions, which have been included here for the reader's convenience.

Research question 1. To what extent does the combination of MAP grammar and task complexity affect measures of syntactic complexity?

The results on the posttest show measures of syntactic complexity are mixed. However, in general there is very little difference between the experimental and control groups in terms of syntactic complexity. Table 5 shows the descriptive statistics for measures of syntactic complexity for the experimental group, whereas Table 6 shows statistically significant descriptive measures of syntactic complexity for the control group, specifically causative constructions.

Table 7 shows the results of two-tailed paired samples $t$ tests for all measures of syntactic complexity for the experimental group. For the first measure of overall complexity - the mean number of words/t-units - the result on the pretest $(M=7.01$, $S D=1.64)$ was less than on the posttest $(M=7.30, S D=1.91)$ for conditions $t(89)=-1.45$, $\mathrm{p} \leq .05$. However, this increase was not statistically significant. For the second measure of overall complexity - the number of words/sentence - the pretest result $(M=8.64, S D=$ 1.64) was greater when compared to the posttest result $(M=8.30, S D=1.91)$ for conditions $t(89)=-1.45, \mathrm{p} \leq .05$. This decrease was statistically significant. For subordination, or the use of dependent clauses, there was also a statistically significant decrease from the pretest $(M=1.20, S D=0.22)$ to the posttest $(M=1.12, S D=0.18)$ for conditions $t(89)=3.00$, $\mathrm{p} \leq .05$, meaning learners decreased their use of dependent clauses on the posttest.

For sub-clausal complexity, the increase in nominal or infinitival clauses from the pretest $(M=5.93, S D=1.26)$ to the posttest $(M=6.57, S D=1.56)$ for conditions $t(89)=-3.46, \mathrm{p} \leq .05$ was statistically significant (see Table 7 ). For the control group, the results on the above measures were not statistically significant.

For causative constructions, or causative expressions showing a connection between a person's action and its effect, a statistically significant increase was shown for both the experimental and control group. The experimental group's pretest $(M=0.12, S D=0.19)$ mean score increased on the posttest $(M=0.30, S D=0.18)$ for conditions $t(89)=-6.78$, $\mathrm{p} \leq .05$ (see Table 7). However, this gain is smaller than the gain made by the control group when their pretest $(M=0.06, S D=0.12)$ is compared to their posttest $(M=0.41$, $S D=0.29$ ) for conditions $t(36)=-6.25, \mathrm{p} \leq .05$ (see Table 8 ). The increased use of causative expressions from the pretest to the posttest supports the validity of manipulating task conditions via causal reasoning to increase the cognitive demand on participants in the 
experiment. In other words, tasking learners with outlining the cause and potential effect of an action is more cognitively demanding than tasking them with simply conveying information presented in a picture. The result occurring in both groups also means that MAP grammar was unrelated to the increase, with increased syntactic complexity here arising as a result of increased task complexity associated with TBLT.

Table 5

Experimental Group (N =90) Descriptive Statistics for Syntactic Complexity

\begin{tabular}{lllllllc}
\hline Measure & Test & $M$ & $S D$ & $\mathrm{mdn}$ & $S E$ & Kurtosis & Skewness \\
\hline 1. Overall complexity & pretest & 7.01 & 1.64 & 7.00 & 0.17 & 1.13 & 0.82 \\
$\quad$ (words/t-unit) & posttest & 7.30 & 1.91 & 6.90 & 0.20 & -0.30 & 0.69 \\
2. Overall complexity & pretest & 8.64 & 3.34 & 8.00 & 0.35 & 2.23 & 1.44 \\
$\quad$ (words/sentence) & posttest & 8.01 & 2.34 & 7.73 & 0.25 & -0.64 & 0.48 \\
Subordination & pretest & 1.20 & 0.22 & 1.15 & 0.02 & -1.13 & 0.54 \\
$\quad$ (clauses/t-unit) & posttest & 1.12 & 0.18 & 1.00 & 0.02 & 5.77 & 2.06 \\
Sub-clausal & pretest & 5.93 & 1.26 & 7.00 & 0.13 & 0.24 & 0.57 \\
$\quad$ (words/clause) & posttest & 6.57 & 1.56 & 5.00 & 0.16 & 0.58 & 0.66 \\
Causative constructions & pretest & 0.12 & 0.19 & 0.00 & 0.02 & 3.65 & 1.81 \\
$\quad$ (CC/t-unit) & posttest & 0.30 & 0.18 & 0.25 & 0.02 & -0.07 & 0.22 \\
\hline
\end{tabular}

Table 6

Control Group ( $=37)$ Statistically Significant Measures of Syntactic Complexity

\begin{tabular}{lllllllc}
\hline Measure & Test & $M$ & $S D$ & $\operatorname{mdn}$ & $S E$ & Kurtosis & Skewness \\
\hline $\begin{array}{c}\text { Causative constructions } \\
\text { (CC/t-unit) }\end{array}$ & pretest & 0.06 & 0.12 & 0.00 & 0.02 & 0.38 & 1.49 \\
& posttest & 0.41 & 0.29 & 0.33 & 0.05 & 0.49 & 1.07 \\
\hline
\end{tabular}

Table 7

Experimental Group $(N=90)$ Paired-samples t-Test Results for Syntactic Complexity

\begin{tabular}{|c|c|c|c|c|c|c|}
\hline Measure & $t$ & $d f$ & $\begin{array}{l}\text { Sig. } \\
(2- \\
\text { tailed) }\end{array}$ & $S E$ & $\begin{array}{r}95 \% \\
\text { inte } \\
\text { di }\end{array}$ & $\begin{array}{l}\text { lence } \\
\text { the } \\
\text { ce }\end{array}$ \\
\hline 1. Overall complexity & -1.45 & 89 & 1.99 & 0.20 & 7.70 & 6.90 \\
\hline 2. Overall complexity & 2.03 & 89 & 1.99 & 0.25 & 8.50 & 7.52 \\
\hline Subordination & 3.00 & 89 & 1.99 & 0.02 & 1.16 & 1.08 \\
\hline Sub-clausal & -3.46 & 89 & 1.99 & 0.16 & 6.90 & 6.24 \\
\hline Causative constructions & -6.78 & 89 & 1.99 & 0.02 & 0.33 & 0.26 \\
\hline
\end{tabular}


Table 8

Control Group ( $\mathrm{N}=37$ ) Paired-samples t-Test Results for Statistically Significant Measures of Syntactic Complexity

\begin{tabular}{lcccccc}
\hline Measure & $t$ & $d f$ & $\begin{array}{c}\text { Sig. } \\
(2- \\
\text { tailed })\end{array}$ & $S E$ & $\begin{array}{c}95 \% \text { confidence } \\
\text { interval of the } \\
\text { difference }\end{array}$ \\
\hline Causative constructions & -6.25 & 36 & 2.03 & 0.05 & 0.51 & 0.26 \\
\hline
\end{tabular}

Research question 2. To what extent does the combination of MAP grammar and task complexity affect measures of accuracy?

Table 9 presents descriptive statistics for grammatical accuracy with the increase of both measures of accuracy being statistically significant for the experimental group. The number of error free $\mathrm{t}$-units on the pretest $(M=2.15, S D=1.61)$ increased on the posttest $(M=3.97, S D=0.34)$ for conditions $t(89)=10.87, \mathrm{p} \leq .05$. A similar gain in the ratio of error free $\mathrm{t}$-units to total $\mathrm{t}$-units was found when the pretest $(M=0.61, S D=0.35)$ was compared to the posttest $(M=0.90, S D=0.18)$ for conditions $t(89)=-7.48, \mathrm{p} \leq .05$ (see Table 10). For the control group, all measures of accuracy remained essentially unchanged and were not statistically significant. These results suggest the combination of MAP grammar and TBLT may have contributed to increasing grammatical accuracy on the posttest.

Table 9

Experimental Group $(\mathrm{N}=90)$ Descriptive Statistics for Accuracy

\begin{tabular}{llrrrrrr}
\hline Measure & Test & $M$ & $S D$ & Mdn & $S E$ & Kurtosis & Skewness \\
\hline Error-free t-units & pretest & 2.15 & 1.61 & 2.00 & 0.17 & 0.95 & 0.76 \\
& posttest & 3.97 & 0.34 & 4.00 & 0.14 & -0.16 & 0.05 \\
Error-free t-units / & pretest & 0.61 & 0.35 & 1.00 & 0.04 & -0.81 & -2.00 \\
total t-units & posttest & 0.90 & 0.18 & 1.00 & 0.02 & 3.96 & -0.58 \\
\hline
\end{tabular}

Table 10

Experimental Group $(\mathrm{N}=90)$ Paired-samples $\mathrm{t}$-Test Results for Accuracy

\begin{tabular}{lcccccc}
\hline Measure & $t$ & $d f$ & $\begin{array}{c}\text { Sig. } \\
(2- \\
\text { tailed })\end{array}$ & $S E$ & \multicolumn{2}{c}{$\begin{array}{c}95 \% \text { confidence } \\
\text { interval }\end{array}$} \\
\hline $\begin{array}{l}\text { Error free t-units } \\
\begin{array}{l}\text { Error free t-units / } \\
\text { total t-units }\end{array}\end{array}$ & -7.48 & 89 & 1.99 & 0.02 & 0.94 & 0.86 \\
\hline
\end{tabular}

Research question 3. To what extent does the combination of MAP grammar and task complexity affect measures of fluency? 
Table 11 shows a comparison of descriptive statistics for fluency on the pretest to the posttest. The increase in fluency from the pr-test $(M=1.53, S D=0.80)$ to the posttest $(M=2.15, S D=0.90)$ for conditions $t(89)=-7.89, \mathrm{p} \leq .05$ was statistically significant (see Table 12). For the control group there was no statistically significant difference in fluency. This increase in fluency means the combination of MAP training and TBLT helped the experimental group provide a lengthier explanation of events than the control group.

Table 11

Experimental Group $(\mathrm{N}=90)$ Descriptive Statistics for Fluency

\begin{tabular}{clcccccc}
\hline Measure & Test & $M$ & $S D$ & Mdn & $S E$ & Kurtosis & Skewness \\
\hline Words / & pretest & 1.53 & 0.80 & 1.47 & 0.08 & 1.05 & 0.95 \\
minute & posttest & 2.15 & 0.90 & 1.87 & 0.09 & -0.18 & 0.78 \\
\hline
\end{tabular}

Table 12

Experimental Group $(\mathrm{N}=90)$ Paired-samples $\mathrm{t}-$ Test Results for Fluency

\begin{tabular}{lcccccc}
\hline Measure & $t$ & $d f$ & $\begin{array}{c}\text { Sig. } \\
(2- \\
\text { tailed })\end{array}$ & $S E$ & $\begin{array}{c}95 \% \text { confidence interval } \\
\text { of the difference }\end{array}$ \\
\hline Words / minute & -7.98 & 89.00 & 1.99 & 0.09 & 2.36 & 1.89 \\
\hline
\end{tabular}

The size effect of tests. Table 13 shows the size effect of each measure of complexity, accuracy and fluency. For every measure of syntactic complexity, the control group's writing is equal to or greater than the experimental group's output. However, the same cannot be said for accuracy and fluency. Specifically, there is about an $85 \%$ probability the experimental group's grammatical accuracy will exceed the control group's, and a $69 \%$ probability fluency will be higher.

Table 13

Size Effect for Each Measure of Complexity, Accuracy, and Fluency

\begin{tabular}{lllllllll}
\hline & \multicolumn{3}{l}{ Syntactic Complexity } & & & Accuracy & Fluency \\
\hline Measure & $\begin{array}{l}\text { Words } \\
\text { / t- } \\
\text { units }\end{array}$ & $\begin{array}{l}\text { Words } \\
\text { / sent. }\end{array}$ & Subord & $\begin{array}{l}\text { Sub- } \\
\text { clausal }\end{array}$ & $\begin{array}{l}\text { Causa } \\
\text {-tives }\end{array}$ & $\begin{array}{l}\text { err } \\
\text { free }\end{array}$ & $\begin{array}{l}\text { err } \\
\text { free/ } \\
\text { t-unit }\end{array}$ & $\begin{array}{l}\text { word/ } \\
\text { minute }\end{array}$ \\
\hline Size Effect & -0.19 & 0.28 & -0.49 & 0.08 & -0.57 & 1.29 & 0.96 & 0.74 \\
Exp. $M$ & 7.30 & 8.64 & 1.12 & 6.57 & 0.30 & 3.97 & 0.90 & 2.17 \\
Control $M$ & 7.69 & 8.01 & 1.24 & 6.44 & 0.43 & 1.89 & 0.63 & 1.51 \\
$S D$ & 2.03 & 2.24 & 0.25 & 1.68 & 0.23 & 1.61 & 0.28 & 0.74 \\
$\%$ Probability & -54 & 56 & -66 & 50 & -69 & 88 & 82 & 69 \\
\hline
\end{tabular}

aProbability an experimental group member is higher than a control group member. 


\section{Discussion}

The present study was designed to research the combined effect of MAP grammar and task complexity, under simple and complex task conditions, on the written output of Japanese university L2 learners of English. The first research question asked to what extent the combination of MAP grammar, TBLT, and increased task difficulty affected syntactic complexity. With the exception of causal constructions, syntactic complexity generally remained static or decreased.

For the experimental group, MAP grammar led to a decrease in measures of overall complexity and subordination, whereas measures of sub-clausal complexity increased. However, the size effect of these changes suggests they are small, and it is highly probable the control group's written syntactic complexity is moderately higher than the experimental group's. This interpretation is based on how syntactic complexity is traditionally defined and measured in SLA research - by the length of different grammatical units. Creating longer sentences, t-units, and clauses results in higher levels of syntactic complexity. By only encouraging the lengthening of clauses, MAP grammar reduced syntactic complexity. However, for Halliday (1994), the highest grammar unit is the clause, and thus this accounts for the increase in sub-clausal complexity. Employing traditional syntactic complexity measures, the MAP grammar learners could only have achieved higher written complexity, above the clause level, by creating a clause complex, in which a main clause is attached to other clauses that modify it. The fact that learners did not create many clause complexes is not surprising given the time pressure of the task. With only 15 minutes of writing time, learners chose to accomplish the task by creating a text consisting of a series of MAP tag sequences with clauses of varying length, each separately representing a single functional communicative event within the overall text. The study suggests learners may have internalized how a clause can be used as the central building block for writing. If such is the case, MAP grammar could be serving as pedagogical scaffolding to create a functional step-by-step process to creating written L2 output.

For the final measure of syntactic complexity, causative constructions, the current study found significant increases for both the experimental and control groups. On the posttest, learners were tasked with not simply describing the picture, but with reasoning out the connection between a traffic violation and potential impending events. The posttest's requirement of greater functional complexity was met by learners' increased linguistic complexity, and was unrelated to MAP grammar. An explanation for the increase in the complexity of causative constructions could come from Wolff's (2003) study of the linguistic coding of intentional versus unintentional events. He showed people preferred lexical constructions to depict an intentional outcome of an event. For events viewed as unintentional, or involving an intermediate object, people tended to choose periphrastic constructions, which are more syntactically complex. On the pretest, learners simply described the picture, but on the posttest they had to describe the potential outcomes of drivers' behaviour. The potential outcomes included such events as a car accident or a traffic ticket, which learners would not view as intentional. Viewing the outcomes as unintentional may have inclined learners on the posttest to use the more syntactically complex periphrastic constructions, resulting in higher measures of causative constructions. This means the only increase in syntactic complexity was unrelated to MAP grammar, reflecting instead how the increased complexity of the task generated increased written complexity in terms of causative constructions on the part of learners. 
The second research question examined the extent to which the combination of MAP grammar, TBLT, and increased task complexity affected the grammatical accuracy of learners' written output. An analysis of the data revealed significant improvement of the written accuracy of the experimental group, whereas the control group's accuracy remained unchanged. An explanation for these results could possibly rest in MAP grammar's tagging process, which closely aligns classroom content, semantic function, and grammatical form. Meeting the necessary criteria for a tag to be assigned means learners must consider whether a grammatical construction matches the semantic function as well as whether both are aligned correctly with content. For example, a What tag might grammatically consist of an article and a noun, as in the highway, whereas a Where tag would need to be expanded to include a preposition, as in on the highway. This semantic depiction of a location would then be checked against the learners' understanding of content. This creates a triplechecking process in which form, function, and meaning are worked together, giving learners multiple means to check grammatical accuracy. Error correction also plays a part in strengthening grammatical checking since all classroom discussions of form are always related back to the function that the tag assumes in classroom context. In summary, it seems MAP grammar may have played a part in significantly improving the experimental group's accuracy, which could be related to using MAP tags to highlight semantic functions and cross-referencing this function with grammatical form and content. This process may be serving to strengthen the form-to-meaning connection, thereby facilitating a better understanding of how to correctly and functionally apply grammatical form.

Finally, the third research question investigated the extent to which MAP grammar and TBLT, combined with increased task complexity, affected the fluency of learners' written output. Fluency for the experimental group increased significantly, whereas the control group's fluency remained unchanged. An explanation for this may rest with Levelt (1978), who outlined how cognitive L2 skills develop within a complex hierarchical structure in which lower structures are somewhat automated in order to facilitate the higher skills required for meaningful communication. In Levelt's terms, the net benefit of MAP grammar is to automate to some degree clausal construction by establishing a systemized process, which reduces and predetermines many linguistic decisions. By teaching learners to tag related language semantically, by function, and then by providing a fixed starting point and a single predictable sequential order to follow, MAP grammar operationalized the syntagmatic sequence of the language. With MAP grammar, learners may have their attention systematically directed to a sequence of functional choices instrumental to creating grammatically correct output. This systemized process could free up learners' L2 resources; if they have less to consider when they are writing, they may be able to produce written output at a faster pace.

In conclusion, the results of the study show the experimental group improved their written accuracy, fluency, and some aspects of complexity. However, identifying a single factor or specific mechanism for this improvement is more difficult. It seems probable that a combination of factors working in concert contributed to these results. The study does suggest, for all learners, that task complexity increased the cognitive demands of the task and directed learners' attention to more complex encoding of causative constructions. For the experimental group, the combination of MAP grammar, TBLT, and increased task complexity also improved the syntactic complexity of sub-clausal constructions as well as L2 accuracy and fluency. Teasing apart the specific combined effects of MAP grammar practices and TBLT tasks remains the focus of future research. 
For classroom practitioners, the study's implications speak to the advantages of having a process-based means of grammatically explaining and applying the L2. For many L2 learners, making the leap from learning a grammatical form to its almost automated communicative use can be a very difficult and time-consuming endeavour. Employing set operating procedures and semantic labels, MAP grammar provides an alternative set of pedagogic explanations to practitioners to systematically scaffold a process-based understanding of how grammatical form operates in context. Such semantic scaffolding adds step-by-step contextual instructions on how to connect grammatical form to real world use, giving learners more confidence in their efforts to increase L2 accuracy and fluency.

Correspondence should be addressed to James W. Gray.

Email: gray@grayenglish.com

\section{References}

Berry, R. (2010). Terminology in English language teaching: Nature and use. New York, NY: Peter Lang.

Bever, T. G. (2013). The cognitive basis for linguistic structures. In M. Sanz, I. Laka, \& M. $\mathrm{K}$. Tanenhaus (Eds.), Language down the garden path: The cognitive and biological basis for linguistic structures (pp. 1-80). Oxford, United Kingdom: Oxford University Press. https://doi.org/10.1093/acprof:oso/9780199677139.003.0001

Burt, M. K. (1975). Error analysis in the adult EFL classroom. TESOL Quarterly, 9(1), 5363. https://doi.org/10.2307/3586012

Ellis, R. (2003). Task-based language learning and leaching. Oxford, United Kingdom: OUP Oxford.

Ellis, R. (2012). Language teaching research and language pedagogy. Oxford, United Kingdom: Wiley.

Gray, J. W. (2018). Map on the job: Applying the order of meaning to an English for occupational purposes setting. In A. Tajino (Ed.), The order of meanings: $A$ meaning-order approach to pedagogical grammar (pp. 230-239). Oxford, United Kingdom: Routledge.

Halliday, M. A. K. (1985a). Introduction to functional grammar. Oxford, United Kingdom: Routledge.

Halliday, M. A. K. (1985b). It's a fixed word order language is English. ITL - International Journal of Applied Linguistics, 67(1), 91-116. https://doi.org/10.1075/itl.6768.07hal

Halliday, M. A. K. (1994). Spoken and written modes of meaning. In D. Graddol \& O. Boyd-Barret (Eds.), Media texts: Authors and readers (pp. 51-73). Clevedon, United Kingdom: Multilingual Matters.

Hunt, K. (1965). Grammatical structures written at three grade levels. (Urbana, IL: The National Council of Teachers of English Research Report No. 3.). Retrieved from https://files.eric.ed.gov/fulltext/ED113735.pdf

Ishikawa, T. (2007). The effects of increasing task complexity along the $+/-$ here-and-now dimension. In M. D. P. G. Mayo (Ed.), Investigating tasks in formal language learning (pp. 136-156). Clevedon, United Kingdom: Multilingual Matters.

Jojima, T., Oyabu, H., \& Jinnouchi, Y. (2018). Developing a base of English expressions using MAP grammar. In A. Tajino (Ed.), The order of meanings: A meaning-order 
approach to pedagogical grammar (pp. 175-184). Oxford, United Kingdom: Routledge.

Kurihara, N., Kawanishi, K., \& Sakamoto, K. (2018). MAP grammar and relative clauses in EFL learners' writing. In A. Tajino (Ed.), The order of meanings: A meaning-order approach to pedagogical grammar (pp. 148-159). Oxford, United Kingdom: Routledge.

Levelt, W. J. M. (1978). Speaking: From intention to articulation. Cambridge, MA: MIT Press.

Levinson, S. C. (1983). Pragmatics. Cambridge, United Kingdom: Cambridge University Press.

Long, M. H. (1991). Focus on form: A design feature in language teaching methodology. In K. De Bot, R. Ginsberg, \& C. Kramsch (Eds.), Foreign language research in crosscultural perspectives (pp. 39-52). Amsterdam, Netherlands: John Benjamins.

Long, M. H. (2000). Focus on form in task-based language teaching. In H. Lambert \& E. Shohamy (Eds.), Language policy and pedagogy (pp. 371-394). Amsterdam, Netherlands: John Benjamins Publishing Company.

Long, M. H. (2003). Stabilization and fossilization in interlanguage development. In C. J. Doughty \& M. H. Long (Eds.), The handbook of second language acquisition (pp. 487-535). Oxford, United Kingdom: Blackwell Publishing.

Long, M. H. (2009). Methodological principles for language teaching. In M. H. Long \& C. J. Doughty (Eds.), The handbook of language teaching (pp. 371-394). Oxford, United Kingdom: Wiley.

Long, M. H., \& Robinson, P. (1998). Focus on form: Theory, research and practice. In C. Doughty \& J. Williams (Eds.), Focus on form in classroom second language acquisition (pp. 15-41). Cambridge, United Kingdom: Cambridge University Press.

Lyster, R., \& Ranta, L. (1997). Corrective feedback and learner uptake: Negotiation of form in communicative classrooms. Studies in Second Language Acquisition, 19(1), 37-66. Retrieved from http://citeseerx.ist.psu.edu/viewdoc/download?doi=10.1.1.529.2765\&rep=rep1\&typ $\mathrm{e}=\mathrm{pdf}$

Narahara, T. (2002). The Japanese copula: Forms and functions. New York, NY: Palgrave Macmillan.

Prabhu, N. S. (1987). Second language pedagogy. Oxford, United Kingdom: Oxford University Press.

Révész, A., Michel, M., \& Gilabert, R. (2016). Measuring cognitive task demands using dual-task methodology, subjective self-ratings, and expert judgments: A validation study. Studies in Second Language Acquisition, 38(4), 703-737. https://doi.org/10.1017/s0272263115000339

Révész, A., Sachs, R., \& Hama, M. (2014). The effects of task complexity and input frequency on the acquisition of the past counterfactual construction through recasts. Language Learning, 64(3), 615-650. https://doi.org/10.1111/lang.12061

Robinson, P. (2001). Task complexity, task difficulty, and task production: Exploring interactions in a componential framework. Applied Linguistics, 22(1), 27-57. https://doi.org/10.1093/applin/22.1.27

Robinson, P. (2005). Cognitive complexity and task sequencing: Studies in a componential framework for second language task design. IRAL - International Review of Applied 
Linguistics in Language Teaching, 43(1), 1-32.

https://doi.org/10.1515/iral.2005.43.1.1

Robinson, P. (2007a). Criteria for grading and sequencing pedagogic tasks. In M. D. P. G. Mayo (Ed.), Investigating tasks in formal language learning (pp. 7-27). Clevedon, United Kingdom: Multilingual Matters.

Robinson, P. (2007b). Task complexity, theory of mind, and intentional reasoning: Effects on L2 speech production, interaction, uptake and perceptions of task difficulty. IRAL - International Review of Applied Linguistics in Language Teaching, 45(3), 193-213. https://doi.org/10.1515/iral.2007.009

Robinson, P. (2011). Task-based language learning: A review of issues. Language Learning, 61(s1), 1-36. https://doi.org/10.1111/j.1467-9922.2011.00641.x

Sato, M. (2011). Constitution of form-orientation: Contributions of context and explicit knowledge to learning from recasts. Canadian Journal of Applied Linguistics, 14(1), 1-28. Retrieved from https://journals.lib.unb.ca/index.php/CJAL/article/view/19864

Shintani, N. (2013). The effect of focus on form and focus on forms instruction on the acquisition of productive knowledge of L2 vocabulary by young beginning-level learners. TESOL Quarterly, 47(1), 36-62. https://doi.org/10.1002/tesq.54

Skehan, P. (1998a). A cognitive approach to language learning. Oxford, United Kingdom: OUP Oxford.

Skehan, P. (1998b). Task-based instruction. Annual Review of Applied Linguistics, 18, 268286. https://doi.org/10.1017/s0267190500003585

Smithers, R. W. (2018). Role-play interviews with MAP grammar. In A. Tajino (Ed.), The order of meanings: A meaning-order approach to pedagogical grammar (pp. 212221). Oxford, United Kingdom: Routledge.

Smithers, R. W., \& Gray, J. W. (2018). Enhancing the quality of life in lifelong learners: The influence of a meaning-order approach to pedagogical grammar on motivation and self-efficacy. Applied Linguistics Review. Advance online publication. https://doi.org/10.1515/applirev-2017-0095

Spada, N., \& Tomita, Y. (2010). Interactions between type of instruction and type of language feature: A meta-analysis. Language Learning, 60(2), 263-308. https://doi.org/10.1111/j.1467-9922.2010.00562.x

Tajino, A. (2018). MAP grammar: Towards a systemic approach to ELT. In A. Tajino (Ed.), The order of meanings: A meaning-order approach to pedagogical grammar (pp. 9-25). Oxford, United Kingdom: Routledge.

Wolff, P. (2003). Direct causation in the linguistic coding and individuation of causal events. Cognition, 88(1), 1-48. https://doi.org/10.1016/s0010-0277(03)00004-0

Yang, Y., \& Lyster, R. (2010). Effects of form-focused practice and feedback on Chinese EFL learners' acquisition of regular and irregular past tense forms. Studies in Second Language Acquisition, 32(02), 235-263. https://doi.org/10.1017/s0272263109990519. 